\title{
Increasing Energy Efficiency Using Photovoltaic Panels
}

\author{
Horatiu POP \\ Bases of Electronics Department \\ Technical University of Cluj-Napoca \\ Cluj-Napoca, Romania \\ Horatiu.Pop@primariaclujnapoca.ro
}

\author{
Alin GRAMA \\ Applied Electronics Department \\ Technical University of Cluj-Napoca \\ Cluj-Napoca, Romania \\ Alin.Grama@ael.utcluj.ro
}

\begin{abstract}
The paper analyses the way of design of photovoltaic systems. The objective of this paper is to study the production capacity of electrical energy and the way it is influenced by real time conditions. In order to realize some energetic models that could be implemented on a large scale and used as a model of good practice we used photovoltaic systems of 3 dimensions: $60 \mathrm{PV}$ panels, $100 \mathrm{PV}$ panels and $160 \mathrm{PV}$ panels respectively. The present study considered the climate conditions of the city of Cluj-Napoca for 12 months. It considered the consumption profile (hourly consumption) and the period of the year (summer, winter, etc.) for 3 typical buildings. We used Matlab/Simulink software for simulations. The result is an estimation of the production of electrical energy for renewable sources and the reduction of GreenHouse Gases (GHG). The aim is to reduce both GHG and the energy consumption from conventional sources.
\end{abstract}

Keywords—photovoltaic panels, energy efficiency, simulink

\section{INTRODUCTION}

What are PhotoVoltaic panels (PV) and where can we use them? PV panels are used to transform the solar radiation into electricity. Solar energy is the result of light and radiation heat transformations that are exploited with the help of new technologies to produce solar thermic energy or solar photovoltaic energy and solar electric energy of thermic origin. Solar energy represents a renewable energy source which is eco-friendly and has low impact on the environment. The electric energy produced by PV panels can be used to satisfy directly final consumers, to charge batteries for subsequent usage and to be directed to the power grid.

It is recommended that PV panels are directly connected with final consumers when they use energy during the day, in the seasons with a high solar radiation. Systems with batteries to store energy are usually used when the final consumer is not connected to the distribution energy grid and there is a continuous need of energy, both day and night or the energy is required even in the unfavorable meteorological conditions. Systems with PV panels are connected to the power grid in the case of producers of electrical energy from renewable sources that produce energy for injecting into the power grid in order to gain profit. Another widely used identified variant is when the final consumer wants to produce a percentage of the total consumed energy with the help of the PV panels. In this case, the rest of the necessary energy is supplied by the power grid.

The last scenario is better suited for a consumer connected to the power grid, but who wants to be environmentally friendly and to reduce the quantity of Greenhouse Gas (GHG) exuded in the atmosphere. This type of consumer is an example of good practice by reducing the costs of electrical energy. On the other hand this consumer needs security of power supply in the periods when PV panels do not produce enough energy. Moreover, when the energy production is higher than the consumption, the owner of PV panels may inject the extra power into the grid to gain profit.

\section{Operation OF Photovoltaic PANELS}

A PV panel is made of a secured protection window under which the photovoltaic monocrystalline or multicrystalline cells are connected and fixed on a plastic casing. The PV cells are supported by a frame and connected to a protected socket.

PV panels transform the solar radiation in Direct Current (DC) through photovoltaic effect. An inverter is placed below the panel, which accomplishes the conversion of DC to Alternative Current (AC) and synchronizes it with the power grid. If the internal power grid is connected to the national power grid, a power modulator must be installed to control the injection of power produced by PV sources into the grid. The power modulator allows the power supply from the internal grid. Consumers are supplied with energy produced by PV panels and with energy from the power grid whenever necessary. In this case, the power grid represents the main source of electrical energy because it is a constant and reliable source that does not depend on external factors. A distribution module is connected to the power modulator and ensures the supply from the power grid. A monitoring system of the solar radiation should be installed to monitor permanently the intensity of solar radiation.

A diagram of the system is shown in Fig.1. 


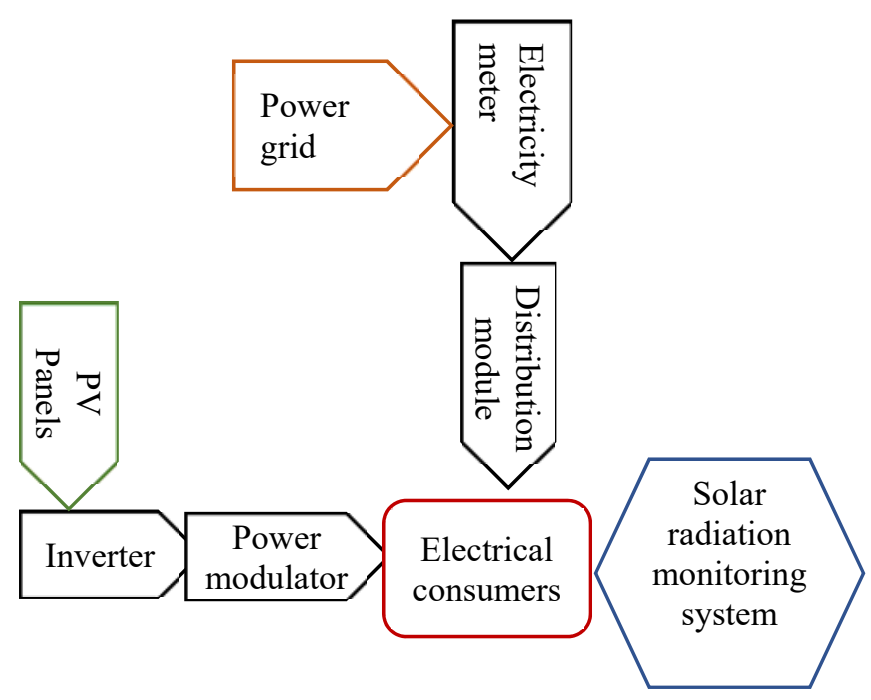

Fig. 1. Diagram of the system.

Production of electrical energy by the PV panels depends on the following factors: the maximum capacity of production of the panel and the intensity of solar radiation. The intensity of solar radiation is influenced by the geographical area where the panel is installed, as well as the meteorological conditions, the position of the sun in the sky, the angle inclination of the Earth axis and the distance between the Earth and the Sun.

In order to get the maximum efficiency, the PV panels should be inclined and oriented respectively. Under favorable atmospheric and temperature conditions, the intensity of solar radiation may reach approximately $1.000 \mathrm{~W} / \mathrm{m}^{2}$.

In Romania, there is potential for using photovoltaic energy especially in the area of Dobrudja Plateau and in the vicinity of the Black Sea shore where the quantity of solar energy may overcome $1400 \mathrm{kWh} / \mathrm{m}^{2} /$ year. In typical situations when the places of installation of PV panels is unknown, the value for IqNOCT $=800 \mathrm{~W} / \mathrm{m}^{2}$ is used, which represents the value of global solar radiation intensity during the testing to determine the normal working temperature of the PV collector.

\section{LOCATION DETAILS}

Cluj-Napoca is the residence city of Cluj county. It is situated between mountains and fields. Its surface is 179,5 $\mathrm{km}^{2}$ and it is situated at the junction of latitude $46^{\circ} 46^{\prime} \mathrm{N}$ with meridian $23^{\circ} 36^{\prime} \mathrm{E}$. The climate of the area is temperate continental. The average annual temperature is $8.2^{\circ} \mathrm{C}$. The geographical coordinates are: latitude $\left(\varphi=46.778^{\circ}\right)$, longitude $\left(\lambda=23.571^{\circ}\right)$.

According to the data from [1], the average annual temperatures for the city of Cluj-Napoca are presented in the Table 1.
TABLE I. MONTHLY TEMPERATURE

\begin{tabular}{|c|c|c|c|c|c|c|c|c|c|c|c|c|}
\hline Month & $\hat{\mathrm{E}}$ & $\frac{1}{3}$ & है & T) & छे & $\stackrel{\Xi}{\Xi}$ & $\vec{\Xi}$ & 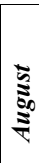 & ڤัँ & ఏัँ & 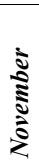 & ڤัँ \\
\hline $\begin{array}{l}\text { Max. } \\
\text { Av. } \\
\left({ }^{\circ} \mathrm{C}\right)\end{array}$ & $\stackrel{m}{0}$ & $\stackrel{\sim}{n}$ & $\hat{a}$ & $\because$ & ?̊. & $\begin{array}{l}0 \\
i \\
\text { in }\end{array}$ & $\stackrel{n}{\sim}$ & $\stackrel{m}{\sim}$ & $\ddot{i}$ & $\begin{array}{l}0 \\
\dot{I}\end{array}$ & ?ֶ. & $\stackrel{\infty}{-}$ \\
\hline $\begin{array}{l}\text { Av. } \\
\left({ }^{\circ} \mathrm{C}\right)\end{array}$ & $\stackrel{+}{\oplus}$ & $\stackrel{\text { Tִ }}{i}$ & Ғ & $a$ & $\stackrel{\sim}{ \pm}$ & $\underset{0}{0}$ & $\stackrel{N}{\infty}$ & $\stackrel{\infty}{\check{N}}$ & 导 & $\dddot{\infty}$ & $\stackrel{+}{i}$ & $\stackrel{n}{1}$ \\
\hline $\begin{array}{l}\text { Min. } \\
\text { Av. } \\
\left({ }^{\circ} \mathrm{C}\right)\end{array}$ & n़ & $\stackrel{r}{\dot{T}}$ & $\begin{array}{l}0 \\
0 \\
1\end{array}$ & ले & $\underset{\infty}{\infty}$ & $\stackrel{?}{=}$ & 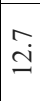 & ปั & $\dot{\infty}$ & $\stackrel{\infty}{\dot{m}}$ & i & भु \\
\hline
\end{tabular}

The average temperature varies from $-3.4^{\circ} \mathrm{C}$ in January reaching $18.2^{\circ} \mathrm{C}$ in July. During the winter there are average negative temperatures and there may be precipitation (snow, sleet). On the other hand, the summers are warm and predominantly sunny, while the temperature may reach over $24{ }^{\circ} \mathrm{C}$.

The diagram of the Sun position on the sky in the city of Cluj-Napoca was establish with the help of the algorithm from the University of Oregon [2] as shown in Fig.2.

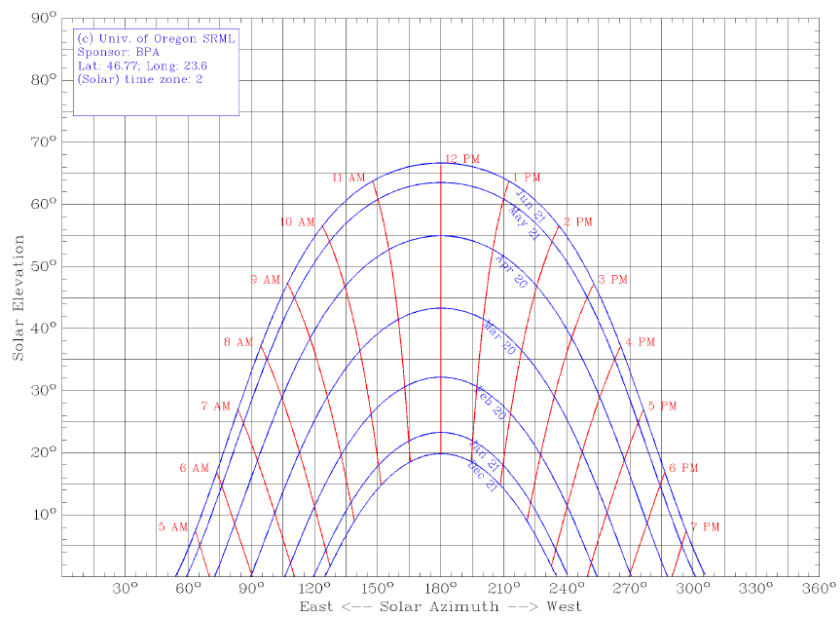

Fig. 2. Sun position for the city of Cluj-Napoca.

The efficiency of a PV panel represents the ratio between the energy from the solar radiation incident on the surface of a PV panel and the electrical energy produced by it. It depends on the environmental temperature and the intensity of solar radiation. The efficiency of a PV panel decreases with increasing environmental temperature and increasing intensity of solar radiation.

After market prospecting we noticed the efficiency of PV panels at an environmental temperature of $25^{\circ} \mathrm{C}$ is between $13-15 \%$ (according to the type of the used PV panel and the value of solar radiation intensity), with the possibility of decreasing till $10-12 \%$ at a temperature of $40^{\circ} \mathrm{C}$.

\section{IMPLEMENTATION}

We have studied the usage of PV panels for producing electrical energy for 365 days. The locations are the following:

- Alexandru Borza High School (60 PV panels)

- Sports High School (100 PV panels)

- Gheorgheni Sports Center (160 PV panels) 
The number of PV panels was established depending on the actual electrical energy consumption, location limitations, building resistance limitations and the roofs orientation.

According to the data available on the NASA website [3], the solar radiation for the city of Cluj-Napoca in the year 2019 is given in Table II.

TABLE II. SOLAR RADIATION

\begin{tabular}{|c|c|c|c|c|c|c|c|c|c|c|c|c|}
\hline Month & है & है & 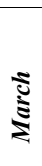 & 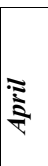 & ङे & $\cong$ & 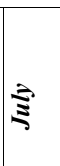 & 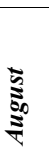 & ڤัँ & ङัँ & 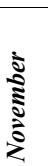 & ڤัँ \\
\hline $\begin{array}{l}\text { average } \\
\text { monthly } \\
\text { solar } \\
\text { radiation } \\
\left(\mathrm{kWh} / \mathrm{m}^{2} /\right. \\
\text { month) }\end{array}$ & $\begin{array}{c}\hat{0} \\
\hat{i}\end{array}$ & $\begin{array}{l}\infty \\
\hat{\sigma}\end{array}$ & $\begin{array}{l}\bar{m} \\
\stackrel{8}{0}\end{array}$ & 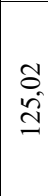 & $\begin{array}{l}\text { m } \\
\stackrel{\text { I }}{I}\end{array}$ & $\begin{array}{l}\infty \\
\tilde{m} \\
\infty \\
\infty\end{array}$ & 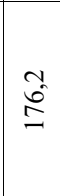 & $\begin{array}{l}\text { ô } \\
\text { ชే } \\
0\end{array}$ & $\begin{array}{l}\text { OD } \\
\infty_{0} \\
=\end{array}$ & $\begin{array}{l}+ \\
\infty \\
\infty\end{array}$ & $\underset{m}{=}$ & $\begin{array}{l}\text { ลे } \\
\text { ें }\end{array}$ \\
\hline \begin{tabular}{|l|} 
average \\
daily solar \\
radiation \\
$\left(\mathrm{kWh} / \mathrm{m}^{2} /\right.$ \\
day)
\end{tabular} & $\frac{⿱}{t}$ & $\begin{array}{l}\stackrel{\infty}{\hat{N}} \\
\underset{v}{v}\end{array}$ & ָे & $\begin{array}{l}\hat{\sigma} \\
\underset{+}{*}\end{array}$ & $\vec{\sigma}$ & $\stackrel{\cong}{=}$ & $\begin{array}{l}\tilde{O} \\
0 \\
\dot{n}\end{array}$ & $\begin{array}{l}\hat{n} \\
\hat{n} \\
n\end{array}$ & $\begin{array}{l}+ \\
\infty \\
\text { r) }\end{array}$ & 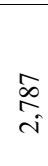 & $\stackrel{\tilde{\approx}}{\cong}$ & $\begin{array}{l}\tilde{2} \\
\stackrel{0}{0}\end{array}$ \\
\hline
\end{tabular}

According to the available data, we may conclude that the maximum productivity is obtained during the summer months (June, July and August). During the winter, the production is approximately 5-6 times smaller than during the summer. In spring and summer months, the level of solar radiation is between $35-70 \%$ of the maximum value.

The table shows that the solar radiations varies between 1 $\mathrm{kWh} / \mathrm{m}^{2} /$ day in the winter and may reach $8 \mathrm{kWh} / \mathrm{m}^{2} /$ day in the summer. During the year, there are over 200 days of production over $2 \mathrm{kWh} / \mathrm{m}^{2} /$ day and over 120 days of productions over $4 \mathrm{kWh} / \mathrm{m}^{2} /$ day.

According to the [4], the average monthly duration of the sun shining in the city of Cluj-Napoca are presented in the following Table III and Fig.3.

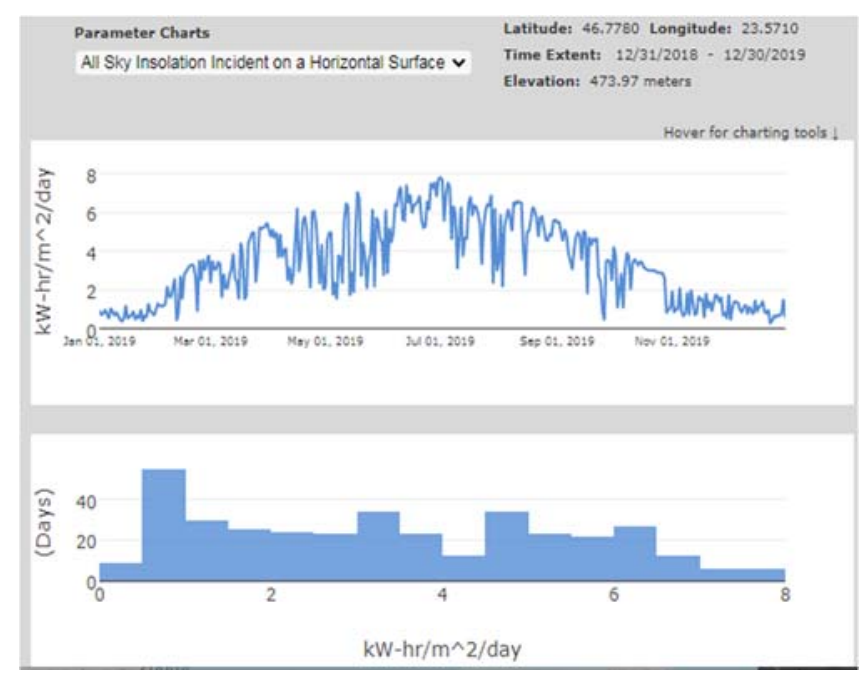

Fig. 3. Daily solar radiation.
TABLE III. SUNSHINE DURATION

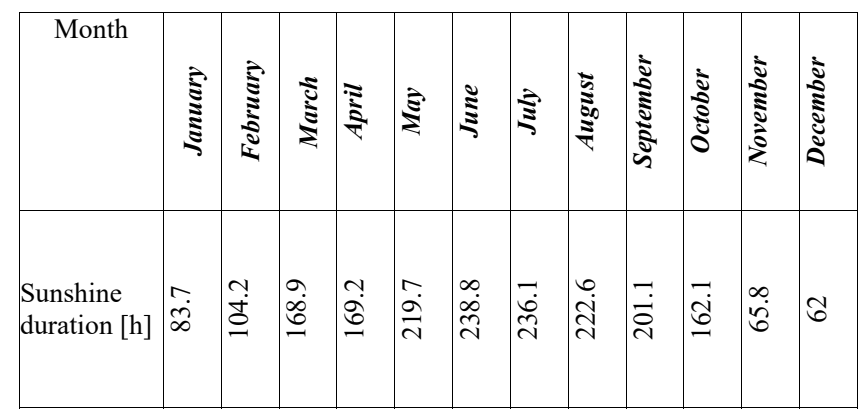

As it was expected, the number of hours of the sunshine is up to 4 times bigger during the summer, which favors the production of electrical energy from PV panels.

\section{Simulation Results}

The parameters of the photovoltaic panel are presented in its datasheet, the most important of them being shown in Table IV.

TABle IV. Photovoltaic Panel Parameters

\begin{tabular}{|l|c|}
\hline & Technical specifications \\
\hline Cell structure & monocrystalline or multicrystalline \\
\hline Output voltage & $12 \ldots 60 \mathrm{Vdc}$ \\
\hline Output power (min.) & $300 \mathrm{w} / \mathrm{panel}$ \\
\hline Protection (min.) & IP67 \\
\hline $\begin{array}{l}\text { Mechanical } \\
\text { resistance (min.) }\end{array}$ & $5400 \mathrm{~N} / \mathrm{m}^{2}$ \\
\hline $\begin{array}{l}\text { Maximum } \\
\text { dimensions }\end{array}$ & $2000 \times 1000 \times 80 \mathrm{~mm}$ \\
\hline Weight & $18 \mathrm{~kg}$ \\
\hline Efficiency (min.) & $15 \%$ \\
\hline $\begin{array}{l}\text { Operation } \\
\text { temperature }\end{array}$ & $-40^{\circ} \ldots+85^{\circ} \mathrm{C}$ \\
\hline
\end{tabular}

The monthly consumption curve in the 3 locations for 2019 are shown in Table V.

TABLE V. MONTHLY CONSUMPTION [MWH]

\begin{tabular}{|c|c|c|c|c|c|c|c|c|c|c|c|c|}
\hline Month & $\stackrel{\vec{\Sigma}}{\mathrm{E}}$ & 焉 & $\stackrel{\Xi}{\Xi}$ & 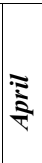 & छे & $\Xi$ & $\vec{\Xi}$ & 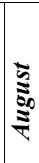 & ఏँ & 㐫 & 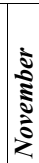 & ఏँ \\
\hline \begin{tabular}{|l} 
Alexandru \\
Borza High \\
School
\end{tabular} & $\underbrace{0}_{0}$ & $\frac{a}{\stackrel{m}{0}}$ & $\stackrel{m}{\tilde{m}}$ & $\begin{array}{l}\stackrel{Y}{\sim} \\
\underset{\sim}{+}\end{array}$ & $\begin{array}{l}\stackrel{+}{\sim} \\
\sim \\
\sim \\
\end{array}$ & $\frac{\infty}{\curvearrowright}$ & ন্ড & $\begin{array}{c}\tilde{\alpha} \\
\tilde{m} \\
\tilde{m}\end{array}$ & $\begin{array}{l}\infty \\
\sim \\
\\
\sim\end{array}$ & $\begin{array}{l}\text { ஸे } \\
\text { రా } \\
\dot{0}\end{array}$ & $\begin{array}{l}m \\
\ddot{\sigma}\end{array}$ & 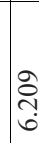 \\
\hline $\begin{array}{l}\text { Sports High } \\
\text { School }\end{array}$ & $\begin{array}{l}\hat{J} \\
\text { in }\end{array}$ & 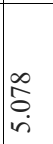 & $\begin{array}{l}\text { J } \\
\text { ọ } \\
\text { in }\end{array}$ & ָ̃ & 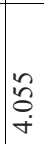 & $\begin{array}{l}\tilde{N} \\
\sim \\
\sim \\
\sim\end{array}$ & 命 & & $\begin{array}{l} \pm \\
\stackrel{2}{7} \\
\dot{m}\end{array}$ & 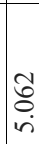 & 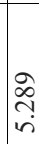 & $\underset{⿱}{\stackrel{+}{f}}$ \\
\hline
\end{tabular}




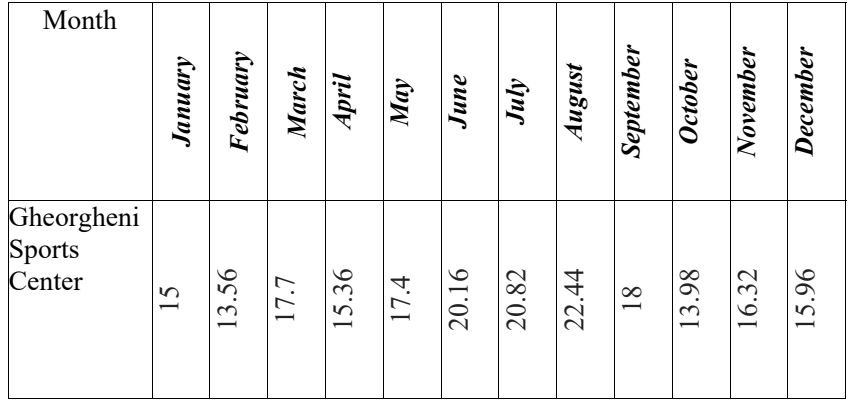

The biggest customer is Gheorgheni Sports Center with a consumption between 13-22MWh/month. The biggest consumption is during the summer. The energy consumption during a year is 203.7 MWh. On the second place of energy consumption is the Borza High School with a yearly consumption of $66.36 \mathrm{MWh}$, followed by Sports High School. In the last case, the yearly consumption is 48.57 MWh. In the case of high schools, the high consumption is done during the courses, reaching its highest point in winter.

For estimating the electrical energy generated by the PV system we used the formula:

$$
E=A \cdot R \cdot H \cdot P R
$$

$\mathrm{E}=$ Produced Energy $(\mathrm{kWh})$

$\mathrm{A}=$ Total area of PV panels $\left(\mathrm{m}^{2}\right)$

$\mathrm{R}=$ the efficiency or performance of PV panels $(\%)$

$\mathrm{H}=$ average solar radiation on PV panels $\left(\mathrm{kWh} / \mathrm{m}^{2}\right)$

$\mathrm{PR}=$ the ratio of performance, losses coefficient (between $0.5-0.9$, default value is 0,75 ).

$\mathrm{R}$ is the efficiency of the solar panel given by the ratio: electrical energy ( $\mathrm{kWp}$ ) of a solar panel divided to the area of a panel. This ratio is given for Standard Testing Conditions (STC): radiation $=1000 \mathrm{~W} / \mathrm{m}^{2}$, cell temperature $=25^{\circ} \mathrm{C}$, wind velocity $=1 \mathrm{~m} / \mathrm{s}, \mathrm{AM}=1.5$. The unit of the nominal power of the PV panel is called Watt-peak.

$\mathrm{H}$ is the average annual solar radiation on the inclined PV panels. Its value varies between $200 \mathrm{kWh} / \mathrm{m}^{2}$ (Norway) and $2600 \mathrm{kWh} / \mathrm{m}^{2}$ (Saudi Arabia). In Romania the value is between $1100-1600 \mathrm{kWh} / \mathrm{m}^{2}$.

PR (performance report) is a very important value for evaluating the quality of a PV system, because it offers the performance regardless of the orientation or inclination of the panel. It includes all the losses. The conversion efficiency from $\mathrm{DC}$ to $\mathrm{AC}$ is considered $86 \%$.

One example of detailed loss of energy that contributed to the value of performance report depend on the application, technology, and proportion of the system:

- loss linked to the inverter (4-14\%)

- temperature loss (5-18\%)

- $\quad$ loss related to AC cables (1-3\%)

- $\quad$ loss related to DC cables (1-3\%)

- margin of error (0-80\%)

- $\quad$ loss linked to weak solar radiation (3-7\%)

- $\quad$ loss caused by dust, snow (2\%)

- other losses

The data may be customized depending on every location with the help of the simulation completed with Matlab/Simulink packet software. We used monthly values of solar radiation for Cluj-Napoca during the simulations in order to have an accurate picture. The number of PV panels may be changed according to the needs. The general picture of the application may be seen in Fig.4.

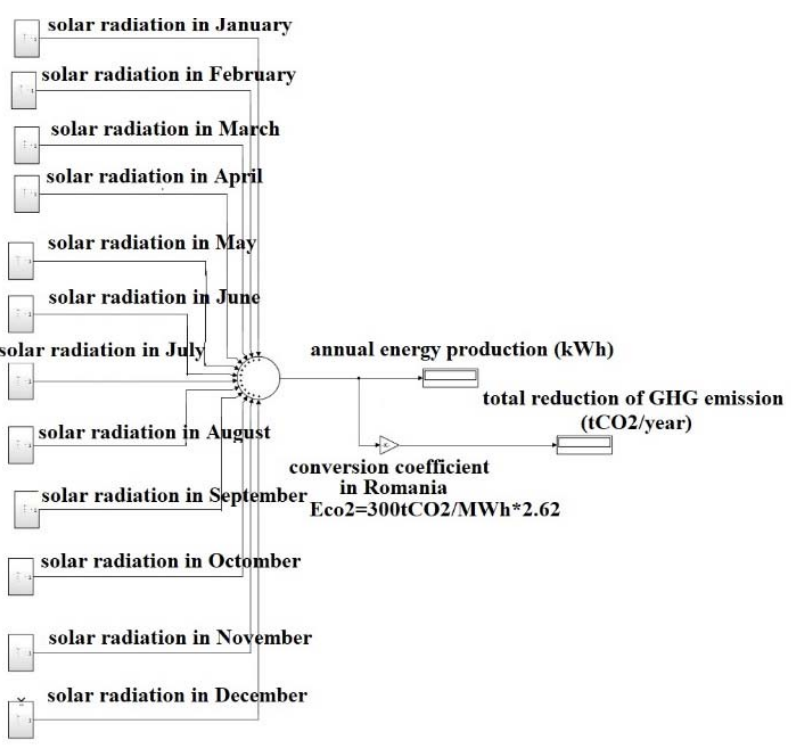

Fig. 4. Main diagram of the application.

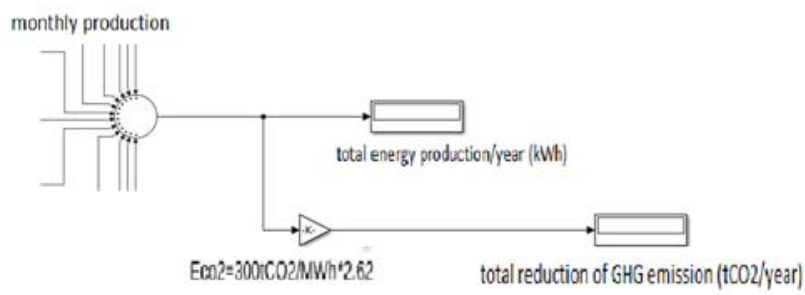

Fig. 5. Detail of main diagram.

The system consists in 12 subsystems (one subsystem for each calendar month for which the simulation was done), a subsystem that gathers the monthly production and a display of yearly consumption. Another display shows the quantity of the reduced GHG. An important element to consider for energetic efficiency projects is the quantity of reduced GHG after implementing the project. GHG are gasses that cover the atmosphere of the Earth by retaining the heat and warming the surface of the Earth through the so-called "greenhouse effect". The main gasses are $\mathrm{CO}_{2}, \mathrm{CH}_{4}, \mathrm{~N}_{2} \mathrm{O}$.

The subsystem corresponding to each month is presented in Fig. 6.

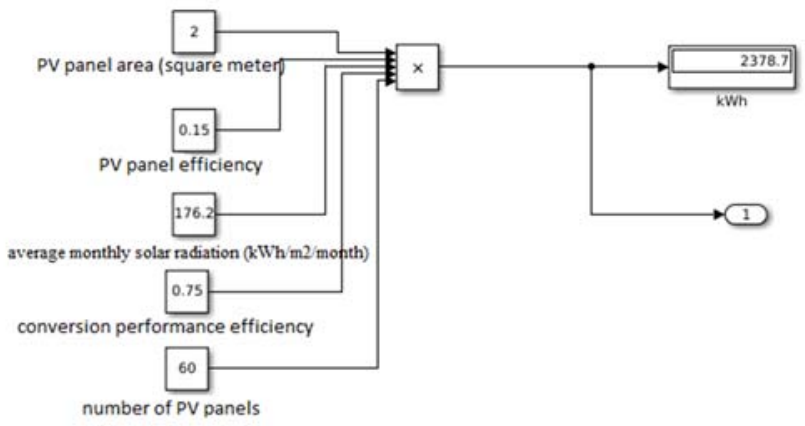

Fig. 6. The subsystem corresponding to one month. 
The entry data for each month are: the surface of the PV panel in $\mathrm{m}^{2}$, efficiency of the PV panel, solar radiation (the monthly average in $\mathrm{kWh} / \mathrm{m}^{2}$ ), the performance report of conversion and the number of PV panels. The result is the total production of $\mathrm{PV}$ panels in the respective month expressed in $\mathrm{kWh}$.

After the simulations we obtained the following results: the quantity of electrical energy produced by renewable sources in a year, for three locations, where a total of $320 \mathrm{PV}$ panels are set is $88934.4 \mathrm{kWh}$.

In order to determine the total reduction of GHG related to the project implementation in 3 locations we used the formula:

$$
E_{\mathrm{CO}_{2}}=\varepsilon \cdot E_{f}
$$

$\varepsilon=300 \mathrm{tCO}_{2} / \mathrm{MWh}$ is the specific level of $\mathrm{CO}_{2}$ emissions according to the electrical energy production in Romania.

The final energy consumption $E_{f} \quad[M W h / y e a r]$ corresponding to real energy consumption of every location $\left[\mathrm{E}_{\mathrm{e}}[\mathrm{MWh}]\right.$, is determined by the equation:

$$
E_{f}=c \cdot E_{e}
$$

$c=2.62$ is the conversion coefficient corresponding to the production of electrical energy in Romania.

We estimate that after the project implementation the GHG emission will be reduced by $69.90 \mathrm{t} \mathrm{CO}_{2} /$ year.

\section{ACKNOWLEDGMENT}

This work was supported by a grant of the Romanian Ministry of Research and Innovation, CCCDI - UEFISCDI, project number 52/2020, PN-III-P2-2.1-PTE-2019-0867, within PNCDI III.

\section{REFERENCES}

[1] The Weather Channel, IBM, www.weather.com

[2] University of Oregon, Solar Radiation Monitoring Laboratory, Sun path chart program,

www. http://solardat.uoregon.edu/SunChartProgram.html

[3] NASA, Power Data Access Viewer, www. https://power.larc.nasa.gov/data-access-viewer/

[4] M. Balan, Energia Solara - Particularitati ale Energiei Solare. Consideratii privind radiatia solara [Solar Energy - Particularities of Solar Energy. Considerations regarding the Solar Radiation],

[5] Ruben Urraca, Thomas Huld, Ana Gracia-Amillo, Francisco Javier, Martinez-de-Pison Frank Kaspar, Andres Sanz-Garcia - "Evaluation of global horizontal irradiance estimates from ERA5 and COSMO-REA6 reanalyses using ground and satellite-based data", journal homepage: www.elsevier.com/locate/solener

[6] Shruti Sharma, Kamlesh Kumar Jain, Ashutosh Sharma a review on "Solar Cells: In Research and Applications", Materials Sciences and Applications, 2015, 6, 1145-1155 Published December 2015, http://dx.doi.org/10.11648/j.ajop.20150305.17

[7] Askari Mohammad Bagher, Mirzaei Mahmoud Abadi Vahid, Mirhabibi Mohsen, Types of Solar Cells and Application, American Journal of Optics and Photonics, Volume 3, Issue 5, October 2015, Pages: 94-113, http://www.sciencepublishinggroup.com/journal/paperinfo?journalid= $127 \&$ doi $=10.11648 /$ j.ajop.20150305.17

[8] Peng et al. (2013). "Review on life cycle assessment of energy payback and greenhouse gas emission of solar photovoltaic systems". Renewable and Sustainable Energy Reviews 19: 255-274. doi:10.1016/j.rser.2012.11.035.

[9] Mathias Berger, David Radu, Raphaël Fonteneau, Robin Henry, Mevl udin Glavic, Xavier Fettweis, Marc Le Du, Patrick Panciatici, Lucian Balea, Damien Ernst - Critical time windows for renewable resource complementarity

assessment, https://doi.org/10.1016/j.energy.2020.117308, Volume 198, 1 May 2020, 117308

[10] Jakub Jurasz, Alexandre Beluco, Fausto A.Canales - The impact of complementarity on power supply reliability of small scale hybrid energy systems, https://doi.org/10.1016/j.energy.2018.07 .182 , Volume 161, 15 October 2018, Pages 737-743 